Abstract-We examined the reactions of fishes to a manned submersible and a remotely operated vehicle (ROV) during surveys conducted in habitats of rock and mud at depths of 30-408 m off central California in 2007. We observed 26 taxa for 10,550 fishes observed from the submersible and for 16,158 fishes observed from the ROV. A reaction was defined as a distinct movement of a fish that, for a benthic or hovering individual, was greater than one body length away from its initial position or, for a swimming individual, was a change of course or speed. Of the observed fishes, 57\% reacted to the $\mathrm{ROV}$ and $11 \%$ reacted to the submersible. Aggregating species and those species initially observed off the seafloor reacted most often to both vehicles. Fishes reacted more often to each vehicle when they were $>1 \mathrm{~m}$ above the seafloor $(22 \%$ of all fishes $>1 \mathrm{~m}$ above the seafloor reacted to the submersible and $73 \%$ to the ROV) than when they were in contact with the seafloor $(2 \%$ of all reactions to the submersible and $18 \%$ to the ROV). Fishes reacted by swimming away from both vehicles rather than toward them. Consideration of these reactions can inform survey designs and selection of survey tools and can, thereby, increase the reliability of fish assemblage metrics (e.g., abundance, density, and biomass) and assessments of fish and habitat associations.

Manuscript submitted 16 February 2012. Manuscript accepted 15 November 2012. Fish. Bull. 111:54-67 (2013).

doi:10.7755/FB.111.1.5

The views and opinions expressed or implied in this article are those of the author (or authors) and do not necessarily reflect the position of the National Marine Fisheries Service, NOAA.

\title{
Reactions of fishes to two underwater survey tools, a manned submersible and a remotely operated vehicle
}

\author{
Thomas E. Laidig (contact author) \\ Lisa M. Krigsman \\ Mary M. Yoklavich \\ Email for address for contact author: tom.laidig@noaa.gov \\ Fisheries Ecology Division \\ Southwest Fisheries Science Center \\ National Marine Fisheries Service, NOAA \\ 110 Shaffer Road \\ Santa Cruz, California 95060
}

Visual surveys of fishes in deep water and untrawlable areas have been conducted more frequently in recent years than in the past largely because of increased availability of underwater vehicles and the need for nonextractive assessments, particularly in no-take areas. These vehicles have provided researchers with the opportunity to gather valuable information on species composition, habitat associations, population density, and various behavioral traits that was previously unattainable in these deep (>30 m), structurally complex areas (Carlson and Straty, 1981; Pearcy et al., 1989; Yoklavich et al., 2007; Laidig et al., 2009; Love et al., 2009). Visual surveys present advantages over traditional sampling methods (e.g., trawling, hook and line, traps) through the use of nondestructive, in situ observations of fishes in their natural habitats.

One concern in counting fishes is their reaction to an observer (e.g., in scuba or snorkel surveys) or underwater vehicle (e.g., submersibles, remotely operated vehicles [ROVs], and camera sleds; Stoner et al., 2008). The vehicles, in particular, can produce a number of electronic and mechanical stimuli (e.g., lights, motion, and noise) that could alter behavior (Krieger, 1993; Uiblein et al.,
2003; Ryer et al., 2009). Accounting for these reactions is an important aspect of accurate population assessments. To this end, Yoklavich et al. (2007) quantified the reactions of fishes to a manned submersible during a survey of Cowcod (Sebastes levis). Cowcod were found to react very little to the submersible, and that low level of reaction strengthened the accuracy of the survey results and associated stock assessment. Other studies have reported fish reactions to both ROVs (Johnson et al., 2003; Trenkel et al., 2004a; Lorance and Trenkel, 2006) and manned submersibles (Murie et al., 1994; Krieger and Sigler, 1996; Gibbons et al., 2002). However, most of these studies were qualitative, simply noting that fishes moved out of the way of the vehicles. More quantitative studies are needed to improve our understanding of the nature and magnitude of reactions of various fish species to a variety of underwater survey vehicles.

The goal of our study was to characterize the reactions of a wide range of marine fish species to 2 commonly used underwater vehicles (a manned submersible and an ROV) during surveys conducted along the seafloor. We quantified the degree of speciesand size-specific reactions of fishes living both on and above the seafloor. 


\section{Materials and methods}

Fish surveys were conducted off central California (Fig. 1) inside and outside of 3 recently created marine protected areas (MPAs)-Point Lobos, Portuguese Ledge, and Soquel Canyon-with the 2-person Delta submersible (Delta Oceanographics, Torrance, CA) and a Phantom DS4 ${ }^{1}$ ROV (Deep Ocean Engineering, San Jose, CA). The manned submersible surveys occurred during the period of 20 September-5 November, 2007, at depths of 30-365 m, and the ROV surveys were conducted during the period of 18-23 November, 2007, at depths of 71-408 m. All surveys were conducted during daylight hours from 0800 to 1700 . Each submersible dive comprised 2-6 transects, each of a 10-min duration. The ROV dives were $1-3 \mathrm{~h}$ in duration. The ROV surveys were conducted along the same path of only a subset of the submersible transects; in other words, not all submersible transects were paired with an ROV dive (Fig. 1).

The Delta submersible (Fig. 2A) was launched from the FV Velero IV and operated by experienced pilots from Delta Oceanographics. An experienced scientific observer accompanied the pilot inside the untethered submersible. This yelloworange submersible was $1.8 \mathrm{~m}$ tall, $4.6 \mathrm{~m}$ long, and from $0.4 \mathrm{~m}$ wide at its forwardmost part to $1.1 \mathrm{~m}$ wide at mid-vehicle. The submersible was equipped with 2 video cameras: 1) a forward-facing, low-light, wide-angle, monochrome camera (Super SeaCam 5000, DeepSea Power and Light, San Diego, CA), and 2) a starboard-mounted, custom-built, color zoom camera with 400 lines of resolution and an illumination range of 2-100,000 lux (Yoklavich and O'Connell, 2008). The position of the Delta submersible was tracked from the support vessel with WinFrog integrated navigation software (Fugro Pelagos, San Diego, CA) and an ORE Trackpoint-II ultra-short baseline (USBL) acoustic system (EdgeTech, West Wareham, MA). The distance traveled was estimated with a ring laser gyro and Doppler velocity $\log$ attached to the outside of the submersible. A single 24-volt propeller provided thrust. During surveys, the Delta traveled at an average speed of $0.5 \mathrm{~m} / \mathrm{s}$, $\sim 1 \mathrm{~m}$ above the seafloor, following a directional heading given to the pilot by scientists aboard the support vessel. The submersible was equipped with ten 150 -watt

\footnotetext{
${ }^{1}$ Mention of trade names or commercial companies is for identification purposes only and does not imply endorsement by the National Marine Fisheries Service, NOAA.
}

halogen bulbs; only 3 of the starboard lights and 1 of the front-mounted forward-facing lights were used to illuminate the transect area.

We also used an unmanned Phantom DS4 ROV launched from and tethered to the NOAA Ship $D a$ vid Starr Jordan and operated by experienced pilots from the National Marine Fisheries Service, Southwest Fisheries Science Center, in La Jolla, California (Fig. 2B). The ROV had a yellow body and black frame and was $1 \mathrm{~m}$ tall, $2 \mathrm{~m}$ long, and $1.4 \mathrm{~m}$ wide. The ROV was equipped with a forward-facing, color video camera (Sony FCB-IX47C, Sony Corp., Tokyo, Japan) with 470 lines of horizontal resolution and an $18 \times$ optical zoom. Like the position of the submersible, the position of the ROV was tracked with WinFrog software and 


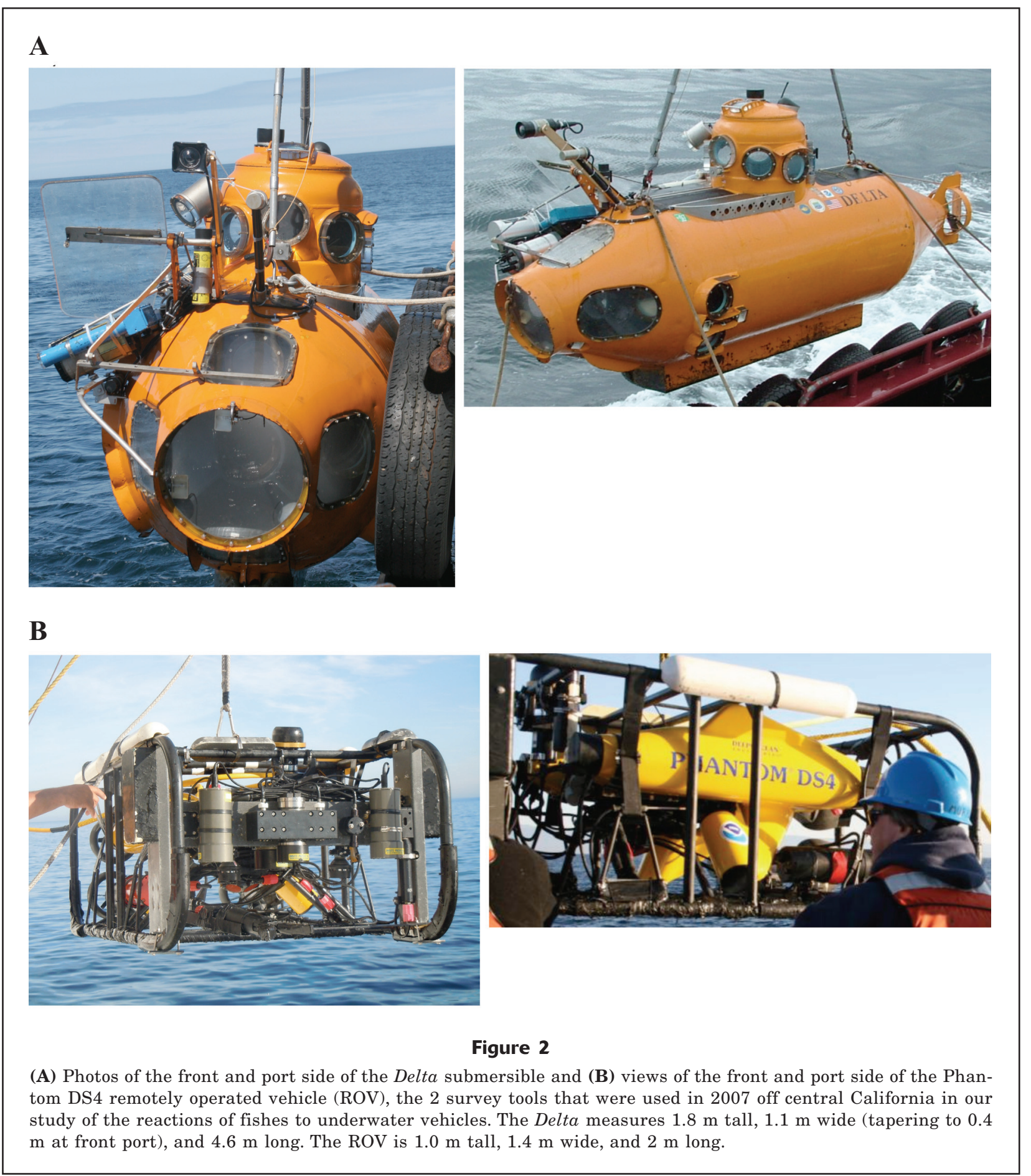

an ORE Trackpoint-II system. The ROV was propelled by 6 electric thrusters ( 2 angled and 4 perpendicular to the seafloor). Surveys were conducted at a target speed of $0.5 \mathrm{~m} / \mathrm{s}$ and a target height of $1 \mathrm{~m}$ above the seafloor. Illumination was provided by two 250 -watt Multi-SeaLite halogen lights from DeepSea Power and Light.
The forward-facing video cameras on each vehicle were used to document fish reactions because these cameras had similar orientations and captured fish reactions in front of both vehicles. Both vehicles also were equipped with lasers to help the observers estimate size of fishes and their distance from the vehicle. The Delta submersible had a pair of parallel lasers 
mounted $20 \mathrm{~cm}$ apart on either side of the color video camera and were visible to the observer inside the submersible. For both vehicles, fishes were measured to the nearest $5 \mathrm{~cm}$. Five lasers were mounted on the front of the ROV; these lasers included 2 pairs of parallel lasers (20 and $60 \mathrm{~cm}$ apart) and a single crossing laser used to determine depth of field. The laser spots on the video footage were used in postsurvey analysis to estimate both the size (total length) of fishes and the distance ahead of the ROV at which a fish reaction occurred. An effort was made to measure all fishes; however, some fishes were either too far away or partially obscured, and, therefore, they could not be measured.

In an important distinction in survey methodology between the 2 vehicles, the scientific observer inside the submersible identified, counted, and estimated length of fishes (as annotated on the audio channel of the video camera), but these tasks were performed only with video footage from the ROV surveys. Video footage from both vehicles was reviewed after completion of the surveys. Fishes in both surveys were identified to the lowest possible taxon with taxonomic keys (Love et al. [2002] for rockfishes, and Miller and Lea [1972] and Eschmeyer et al. [1983] for the remaining fishes).

All fish reactions were determined solely from video footage of the forward-facing cameras on both vehicles in order for the methods to be similar between survey vehicles. A reaction was defined as a distinct movement of a fish if that movement was greater than one body length away from the initial position of the fish. Some fishes that were hovering off the seafloor would turn and face the vehicle as it passed by, but this movement was not considered a reaction unless a fish actively swam at least one body length in any direction. If a fish was swimming in a particular direction when first observed and continued swimming in the same direction at the same speed during the entire time on video, that fish was considered to have no reaction. However, a reaction was noted if a fish changed course or swimming speed.

The initial position of a fish was recorded as 1 of 3 categories: resting on the seafloor, $\leq 1 \mathrm{~m}$ above the seafloor (but not touching the seafloor), or $>1 \mathrm{~m}$ above the seafloor. Direction of fish reaction was recorded as swimming 1) toward the vehicle, 2) parallel, forward, and away from the vehicle, 3) perpendicular to the left, 4) perpendicular to the right, or 5) down toward the seafloor. No fishes were ever recorded moving upward. We used time and an average vehicle speed of $0.5 \mathrm{~m} / \mathrm{s}$ to estimate the distance between a reacting fish and the front of the Delta submersible. The distance between a reacting fish at first sighting and the front of the ROV was estimated with the laser array. This distance was binned to $<3 \mathrm{~m}$ or $3-6 \mathrm{~m}$. A $20-\mathrm{cm}$ fish could be seen at a maximum distance of about $6 \mathrm{~m}$ in front of the ROV and about $9 \mathrm{~m}$ in front of the submersible (because images could be distinguished farther with the low-light, monochrome camera on the submersible compared with the color camera on the ROV). To ensure that results from the ROV and submersible were comparable, we used data only from fishes that occurred at a distance of at most $6 \mathrm{~m}$ from the submersible.

Hagfishes (Eptatretus spp.), thornyheads (Sebastolobus spp.), and young-of-the-year (YOY) rockfishes (Sebastes spp.) were included as taxonomic groups in our analyses. Hagfishes often were seen hiding in holes or under structure and could not be identified to species. However, all the hagfishes that could be identified were Pacific Hagfish (Eptatretus stoutii). The thornyhead group comprised Shortspine Thornyhead (Sebastolobus alascanus), a few Longspine Thornyhead (S. altivelis; 1 observed from the submersible and 4 from the ROV), and mostly unidentified thornyheads. YOY rockfishes were a mix of many species, and each was recorded as $5 \mathrm{~cm}$ in total length.

We determined fish reactions only while the vehicles traveled forward in survey mode. No fish reactions were counted if the seafloor, which we used as a stationary reference for fish movement, was not observed in the video footage for $\geq 5 \mathrm{~s}$ (as when either vehicle transited over narrow ravines or when the ROV was pulled off transect by the ship). A number of species were not considered in our analyses. For instance, pelagic schooling fishes, such as Northern Anchovy (Engraulis mordax), Jack Mackerel (Trachurus symmetricus), and Pacific Chub Mackerel (Scomber japonicus), swam around the vehicles for extended periods of time (possibly because they were attracted to the vehicles, but this idea was not verified), and these long periods of time increased the possibility that fishes would be double counted. These species also darted in and out of the view of the cameras, making it difficult to assess individual reactions to the vehicles. Only species that accounted for $\geq 1 \%$ of the total number of fish observed from either vehicle were included in the analyses of reactions to the vehicles. A chi-square test was used to evaluate reactions relative to initial fish position.

\section{Results}

A total of 223 transects (56 h) were surveyed with the Delta submersible in hard (70\% rock, boulder, and cobble) and soft (30\% mud and sand) seafloor habitat, and 10,550 fishes were observed (Table 1). A total of $10 \mathrm{ROV}$ dives $(21 \mathrm{~h})$ were conducted, and 16,158 fishes were observed. Although the ROV covered only a subset of all submersible dives, the type of habitats surveyed with the ROV (60\% hard and $40 \%$ soft) were similar to those habitats surveyed with the submersible. Water visibility during submersible dives ranged from 4 to 13 $\mathrm{m}$ (as estimated by the submersible pilot during each dive), averaged $8 \mathrm{~m}$, and was greatest at depths $>100$ $\mathrm{m}$. Observations made from the submersible were limited more by light penetration from the submersible ( 9 $\mathrm{m})$ than by water visibility. Observations made from the ROV video footage were confined to $\sim 6 \mathrm{~m}$, because 


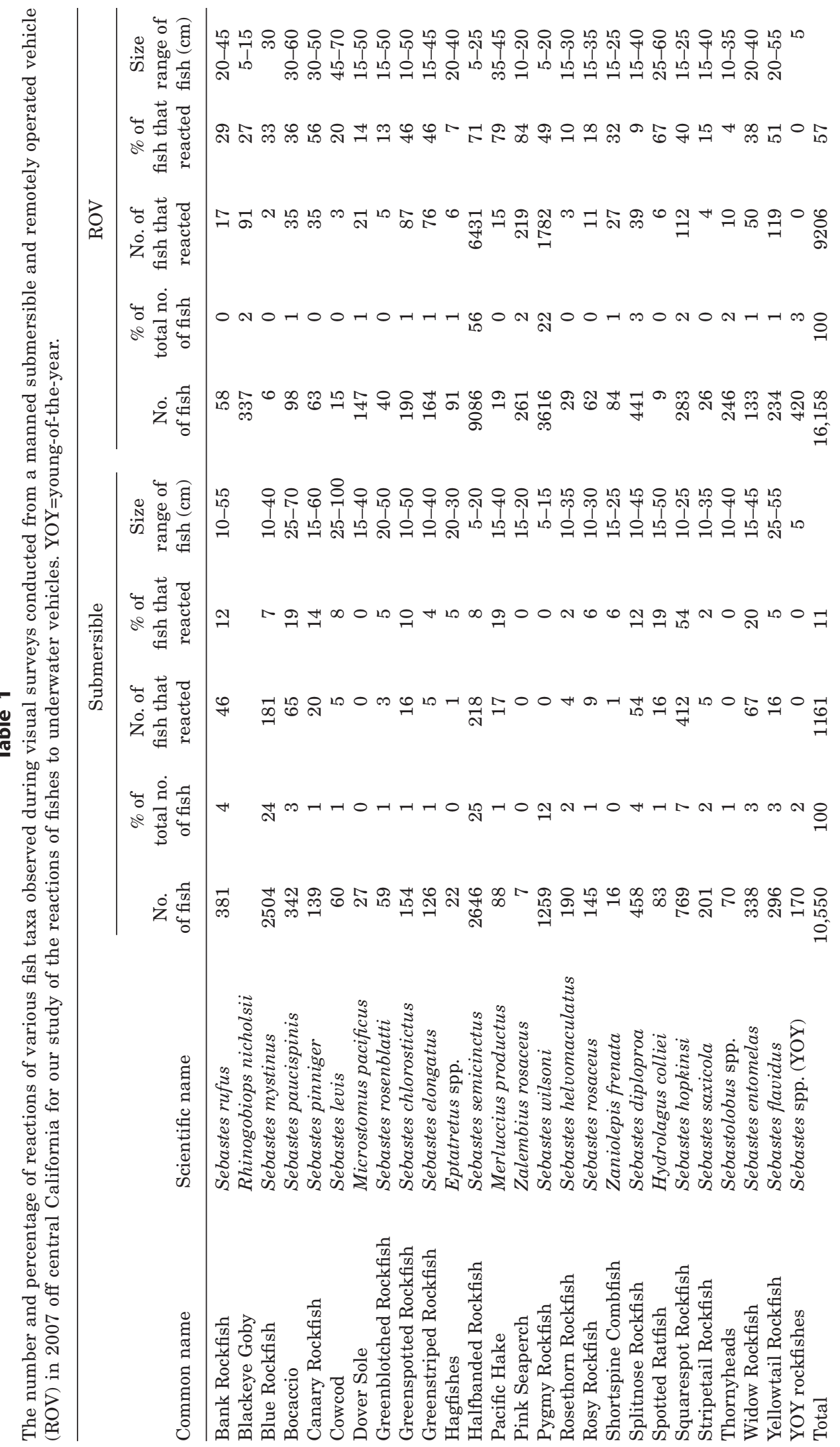


of the type of lighting and camera (see Materials and methods section).

We used 26 taxa of fishes in the analyses of fish reactions to the submersible and ROV (Table 1). Halfbanded (Sebastes semicinctus; 25\%), Blue (S. mystinus; 24\%), and Pygmy (S. wilsoni; 12\%) Rockfishes were the most abundant species observed from the Delta submersible, and Halfbanded (56\%) and Pygmy (22\%) Rockfishes were most abundant in the ROV survey. In total, observations of 1161 fishes for the Delta submersible and 9206 fishes for the ROV were used in the analyses of directional movements and distance of reaction from each vehicle.

Fewer fishes reacted to the manned submersible ( $11 \%$ of all fishes; Table 1 ) than to the ROV (57\% of all fishes). The minimum distance of a fish reaction was $0.5 \mathrm{~m}$ from the submersible $(96 \%$ of reactions were at a distance $\geq 1 \mathrm{~m}$ ) and $1 \mathrm{~m}$ from the ROV. The percent reaction varied from $0 \%$ for several species to $54 \%$ for the Squarespot Rockfish (S. hopkinsi) observed from the submersible and from $0 \%$ for some species to $84 \%$ for Pink Seaperch, (Zalembius rosaceus) for fishes observed from the ROV. Of those taxa observed from the submersible, only Squarespot Rockfish had a reaction rate of at least $50 \%$. Six taxa observed with the ROV had a reaction rate of at least $50 \%$ : Pink Seaperch, Pacific Hake (Merluccius productus), Spotted Ratfish (Hydrolagus colliei), and Yellowtail (S. flavidus), Canary (S. pinniger), and Halfbanded Rockfishes. Cowcod, Bocaccio (S. paucispinis), and Canary Rockfish are of particular concern to fishery managers and in need of improved assessments (Hilborn et al., 2011; PFMC, 2011). The reaction rate of these 3 species to the submersible ranged from $8 \%$ to $19 \%$; their reactions to the ROV varied from $20 \%$ to $56 \%$. Thornyheads, YOY rockfishes, and hagfishes had reaction rates $<10 \%$ to either vehicle. Fishes of 5 taxa did not react at all to the submersible, and 1 group of taxa (YOY rockfishes) that did not react to the ROV.

Fish reactions to both vehicles increased significantly as fish distance above the seafloor increased, and this trend in reaction was greater for the ROV than for the submersible (all fishes combined, $P<0.001$; Table 2; Fig. 3). Only $2 \%$ of the fishes observed on the seafloor during submersible surveys (i.e., 27 of 1261 fishes) and $7 \%$ observed near the seafloor (i.e., 410 of 6009 ) reacted to this vehicle. However, $18 \%$ of fishes on the seafloor (i.e., 512 of 2895) reacted to the ROV, with Halfbanded Rockfish and Blackeye Goby (Rhinogobiops nicholsii) accounting for $71 \%$ of these reactions (361 out of 512 fishes that reacted; Table 2). During the ROV surveys, fishes near the seafloor reacted more than fishes in contact with the seafloor (59\% versus $18 \%$, respectively), with Halfbanded and Pygmy Rockfishes representing $93 \%$ of these reactions (3800 out of 4083 fishes that reacted). Fishes in the midwater, a region defined as $>1$ $\mathrm{m}$ above the seafloor, reacted the most to either vehicle ( $22 \%$ to the submersible and $73 \%$ to the ROV). Squarespot and Blue Rockfishes represented $80 \%$ of the midwa- ter reactions to the submersible, and Halfbanded and Pygmy Rockfishes accounted for $90 \%$ of the reactions of midwater fishes to the ROV. This pattern of greater percentage of reactions with increased height off the seafloor was observed for most individual taxa. Even those species that are primarily demersal, like Cowcod and Greenstriped ( $S$. elongatus) and Greenspotted ( $S$. chlorostictus) Rockfishes, exhibited this pattern in observations from both the submersible and ROV.

The fishes that demonstrated any type of reaction to each vehicle primarily swam away rather than toward the vehicles (Fig. 4; Table 3, A and B). Only a small percentage $(0-8 \%)$ of fishes swam toward either vehicle; most of these fishes were Bocaccio near the seafloor, and 19 of 50 of those Bocaccio reacted by swimming toward the submersible. Most fishes either moved away (forward, ahead of the vehicle) or sideways (to the left or right). However, $37 \%$ of all fishes in the midwater reacted by swimming downward when initially encountered by the submersible (Table 3A). This group was dominated by Blue, Widow (S. entomelas), and Splitnose (S. diploproa) Rockfishes (representing $96 \%$ of those midwater fishes that reacted by swimming down). Only $13 \%$ of all fishes near the seafloor moved downward as the submersible approached; Bocaccio and Widow Rockfish reacted the most in this category ( $20 \%$ and $25 \%$ of all fish that reacted, respectively). Only $1 \%$ of fishes in the midwater or near the seafloor reacted to the ROV by swimming downward (Table 3B).

The distance at which a fish reaction occurred varied between vehicles (Table 4; Fig. 5). Blue, Halfbanded, Widow, Bank (S. rufus), and Splitnose Rockfishes moved at distances $>3 \mathrm{~m}$ in front of the submersible. These species often were located in the midwater or near the seafloor. However, some species located most often near the seafloor (e.g., Bocaccio and Canary and Squarespot Rockfishes) reacted more often when the vehicle came closer to them $(<3 \mathrm{~m})$. Seafloor-dwelling species did not react often to the submersible, and, when they did, there was no clear pattern in reactions related to distance in front of the vehicle. The species that reacted farthest in front of the ROV were Halfbanded, Widow, and Yellowtail Rockfishes, all of which were found near the seafloor or in the midwater. Species that reacted closer $(<3 \mathrm{~m})$ to the ROV included fishes living almost entirely on the seafloor (e.g., Blackeye Goby, Shortspine Combfish [Zaniolepis frenata], and Greenstriped Rockfish), as well as some near the seafloor and in the midwater (e.g., Bocaccio and Canary, Greenspotted, Rosy [S. rosaceus], Splitnose, and Squarespot Rockfishes).

Body length was determined for all fishes that were observed during the submersible surveys $(n=10,550)$, but only 9177 fishes (57\%) of all fishes observed in video footage from the ROV surveys were measured. Total length ranged from 5 to $100 \mathrm{~cm}$ for fishes observed from the submersible and from 5 to $70 \mathrm{~cm}$ for fishes seen during the ROV surveys. Most fishes were 


\begin{tabular}{|c|c|c|c|c|}
\hline 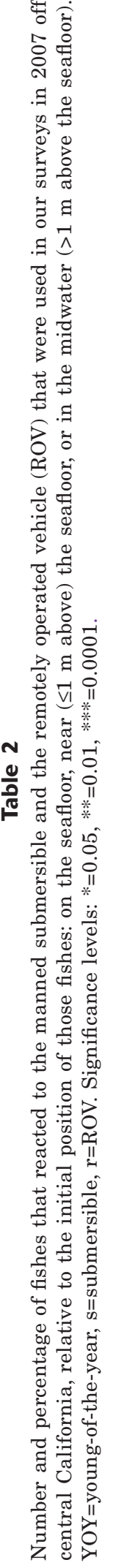 & 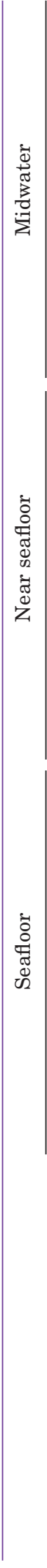 & 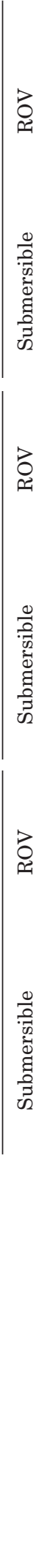 & 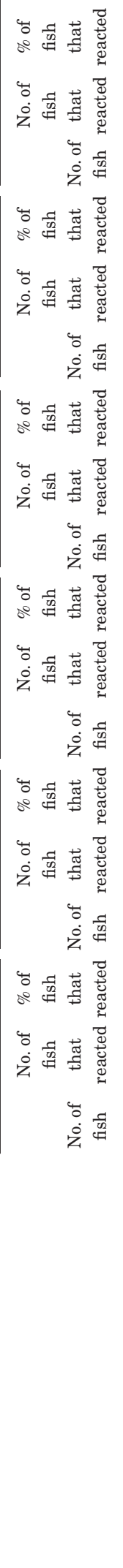 & 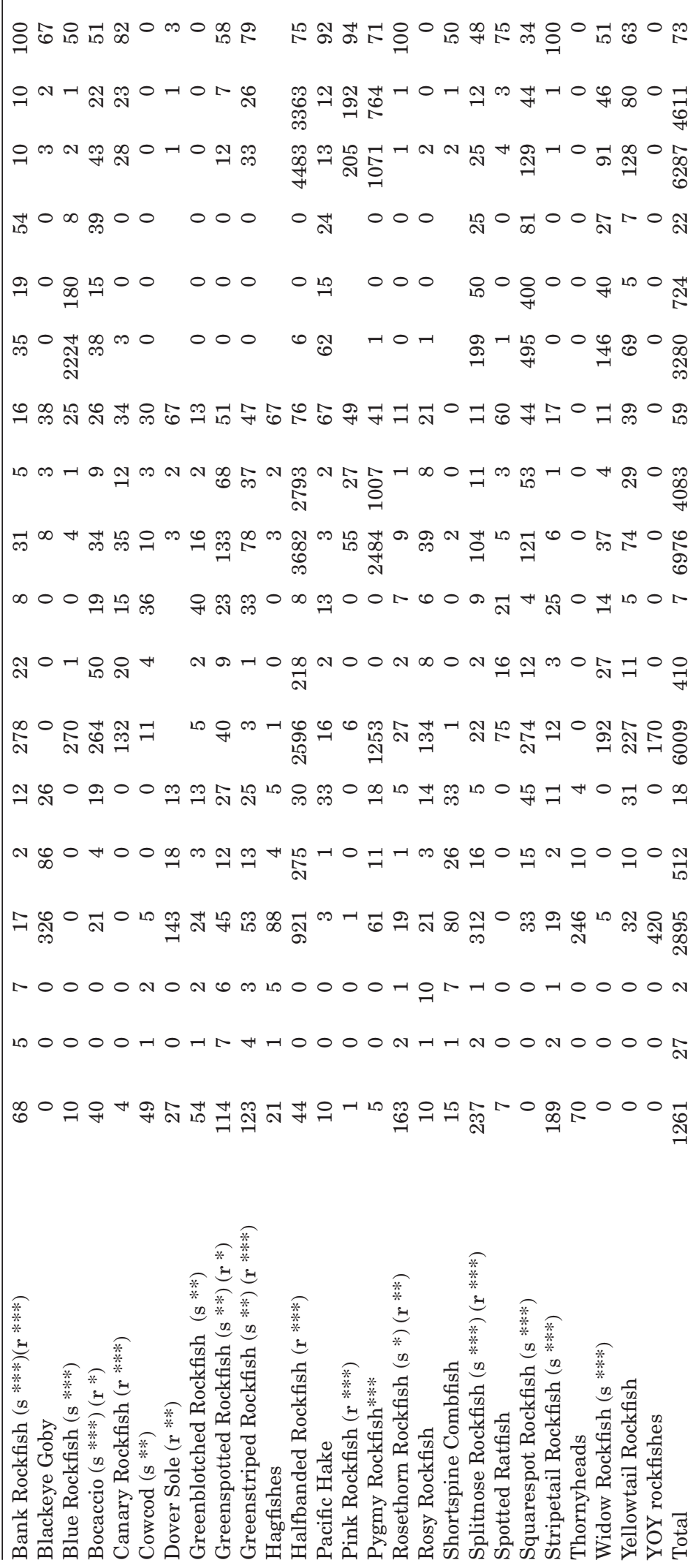 \\
\hline
\end{tabular}


$20 \mathrm{~cm}$ or less in length $(68 \%$ of all fishes in the submersible surveys and $89 \%$ in the ROV surveys). The fishes that were $\leq 20 \mathrm{~cm}$ in total length accounted for $75 \%$ of all reactions observed from the submersible and $94 \%$ of all reactions observed in video footage from the ROV surveys.

\section{Discussion}

Although fishes reacted to both survey vehicles, there were proportionally greater numbers of reactions to the ROV than to the submersible. The ROV and submersible traveled at similar speeds and maintained similar heights off the seafloor, yet substantial differences were observed in fish reactions to the 2 vehicles. Possible reasons for these differences in reactions include the presence of a tether that attaches the ROV to the support ship (the manned submersible is autonomous and untethered), forward lighting on the ROV compared with lighting largely on the starboard side of the submersible, differences in vehicle noise, and disparity in vehicle dimensions.

Both vehicles were much larger than common predators (e.g., large fishes and pinnipeds) of most of these species, and we, therefore, surmise that size alone was not the factor that caused fishes to react. It is possible that the smaller ROV, which was about one-half the height and length of the submersible, appeared to be more like a large predator to the fishes than did the submersible, but this idea is difficult to establish.

The magnitude of pressure waves generated in front of each vehicle could have differed because the submersible was of solid construction and the ROV comprised a frame with attached instruments and a trailing tether. Indeed, pressure waves generated from a deepwater drop-camera system that operated about $130 \mathrm{~m}$ above a midwater aggregation of Orange Roughy (Hoplostethus atlanticus) off Tasmania caused those fishes to disperse rapidly up to $40 \mathrm{~m}$ (Koslow et al. 1995).

Fish reactions to vehicles can also depend on environmental conditions (e.g., type of seafloor sediments, relief, ambient light levels, and water currents) and some attributes of the survey itself (e.g., vehicle speed and height off the seafloor). To reduce the effects of some of these conditions, we surveyed only during daylight hours, in similar habitats, during the same time of the same year, at similar speeds, and at similar heights off the seafloor.

Whatever the reasons that fishes react to survey vehicles, the reaction of the target species must be con-

sidered in selection of underwater vehicles to conduct surveys on fish abundance. Population abundance can be either over-or under-estimated if fish reactions to the survey vehicles are not quantified. Once the reaction rates are determined, correction factors can be developed to account for species-specific differences in reaction to the survey vehicles and to adjust resultant abundance estimates. Knowledge of fish reactions associated with each survey tool can help ascertain the most appropriate survey method for target species.

Clear description and quantification of fish reactions to underwater survey vehicles are not common in the literature. From a review of the literature, fish reactions were defined in only 2 of 37 published papers that reported on the reactions of fishes to underwater vehicles (see review in Stoner et al. 2008; Davis et al., 1997; Krieger and Ito, 1999; Else et al., 2002; Moore et al., 2002; Uiblein et al., 2003; Costello et al., 2005; Gartner et al., 2008; Luck and Pietsch, 2008; Benefield et al., 2009; Trenkel and Lorance, 2011; Baker et al., 2012; O'Connell et al. ${ }^{2}$ ). A fish reaction was defined in one of these 2 articles as a "disturbed" behavior or "differenc-

\footnotetext{
${ }^{2}$ O'Connell, V., D. Carlile, and C. Brylinsky. 2001. Demersal shelf rockfish stock assessment and fishery evaluation report for 2002. Regional Information Report 1J01-35, 42 p. Alaska Dept. Fish Game, Division of Commercial Fisheries, Juneau, AK.
} 

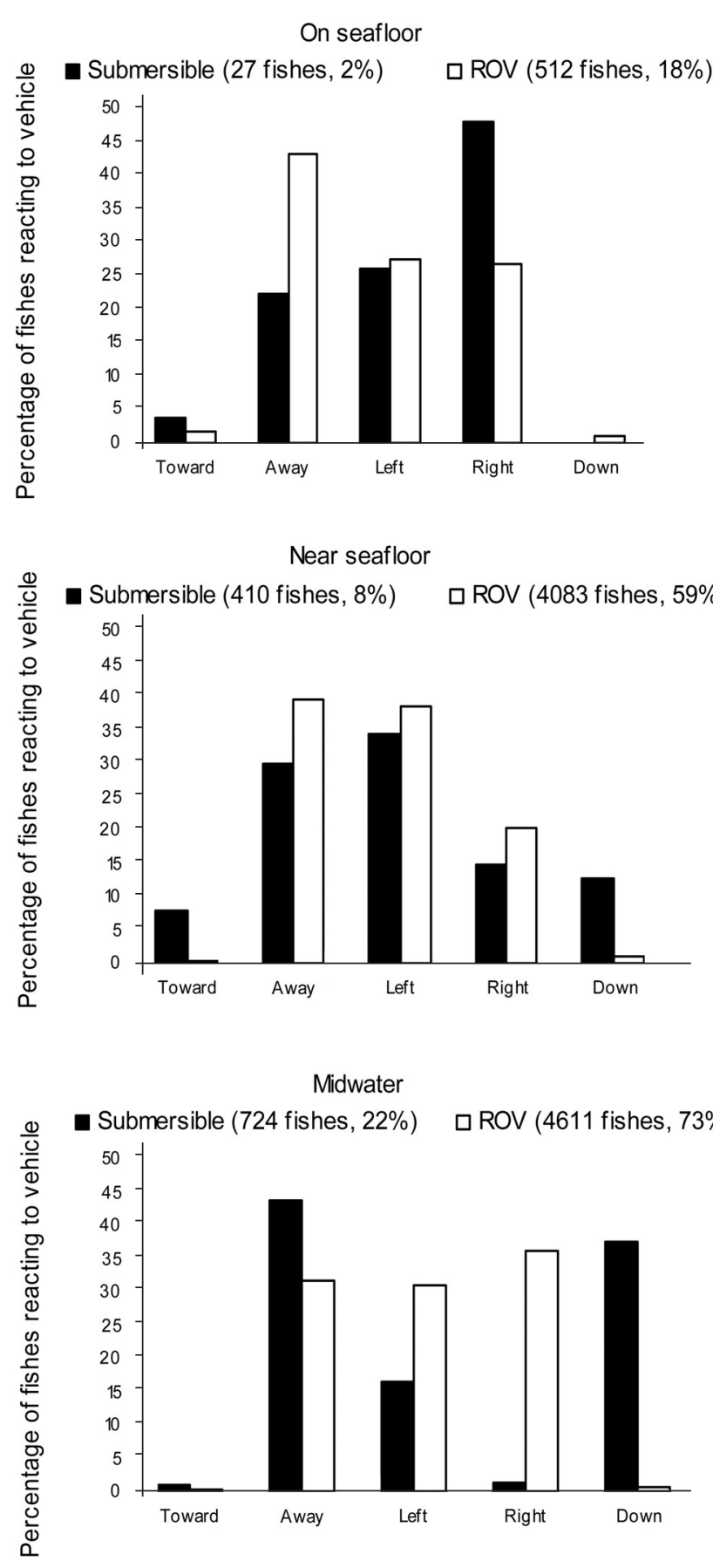

Figure 4

Percentage of fishes that reacted in a particular direction to the manned submersible or the remotely operated vehicle (ROV) that were used in 2007 off central California in our study of the reactions of fishes to underwater vehicles relative to the initial position of those fishes: on the seafloor, near $(\leq 1 \mathrm{~m}$ above) the seafloor, or in the midwater $(>1 \mathrm{~m}$ above the seafloor). Total number of fishes that reacted to each vehicle, and the percentage of the total number of fishes in the survey that reacted, are shown in parentheses for each initial position. es in natural behavior" (Lorance and Trenkel, 2006) and as "a marked change in activity level and/or locomotion behavior" in the other article (Uiblein et al., 2003). General categories of reactions (such as a fish avoided or was attracted to a vehicle, or a fish had no reaction) were used in 6 studies (Adams et al., 1995; Trenkel et al., 2004a; Trenkel et al., 2004b; Costello et al., 2005; Trenkel and Lorance, 2011, Baker et al., 2012), but specific definitions of the reactions (in contrast to natural movements) were not reported for these studies.

In our surveys, reaction of a nonmoving fish was defined as a distinct movement greater than one body length. We used this proportional measure instead of a specific distance because the total length of observed fishes varied from 5 to $100 \mathrm{~cm}$. The use of our definition of a reaction as at least one body length could be problematic, especially for quantification of relatively small movements. However, in our study, the minimum distance that any fish traveled was $0.5 \mathrm{~m}$ in reaction to the submersible (with $96 \%$ of these fishes moving $1 \mathrm{~m}$ or greater) and 1.0 $m$ in reaction to the $\mathrm{ROV}$. Therefore, the reactions of even the smallest fishes could be readily discerned.

It can be argued that a fish in motion when first seen in a video footage was already moving in reaction to the survey vehicles (Uiblein et al., 2003; Lorance and Trenkel, 2006). In our study, we surveyed numerous benthopelagic species that were slowly moving when first observed in the video footage. Such movement was not considered a reaction unless a fish obviously changed course or speed. Because a fish could not be seen before it came into view on a video footage, it could not be determined if that fish was initially motionless and then reacted as the vehicle approached. This type of behavior could be indicated by signs like a dust cloud where a fish had contact with the seafloor, a fish quickly darting into the video footage, or loose aggregations of fishes moving in many different directions. In our study, these types of behavior were rarely, if ever, observed.

Few quantitative studies have been conducted on fish reactions to a submersible or an ROV, and no direct comparisons between the reactions of specific fish species to a submersible and ROV have been found in the literature. General reactions to an ROV (fishes moving into and out of a video frame) were quantified during surveys on mud habitats off central California (Adams et al., 1995). In that study, most fishes that occurred on the seafloor did not react to a relatively large working-class ROV, although 2 species typically observed off the seafloor exhibited avoidance behavior: $44 \%$ of all 


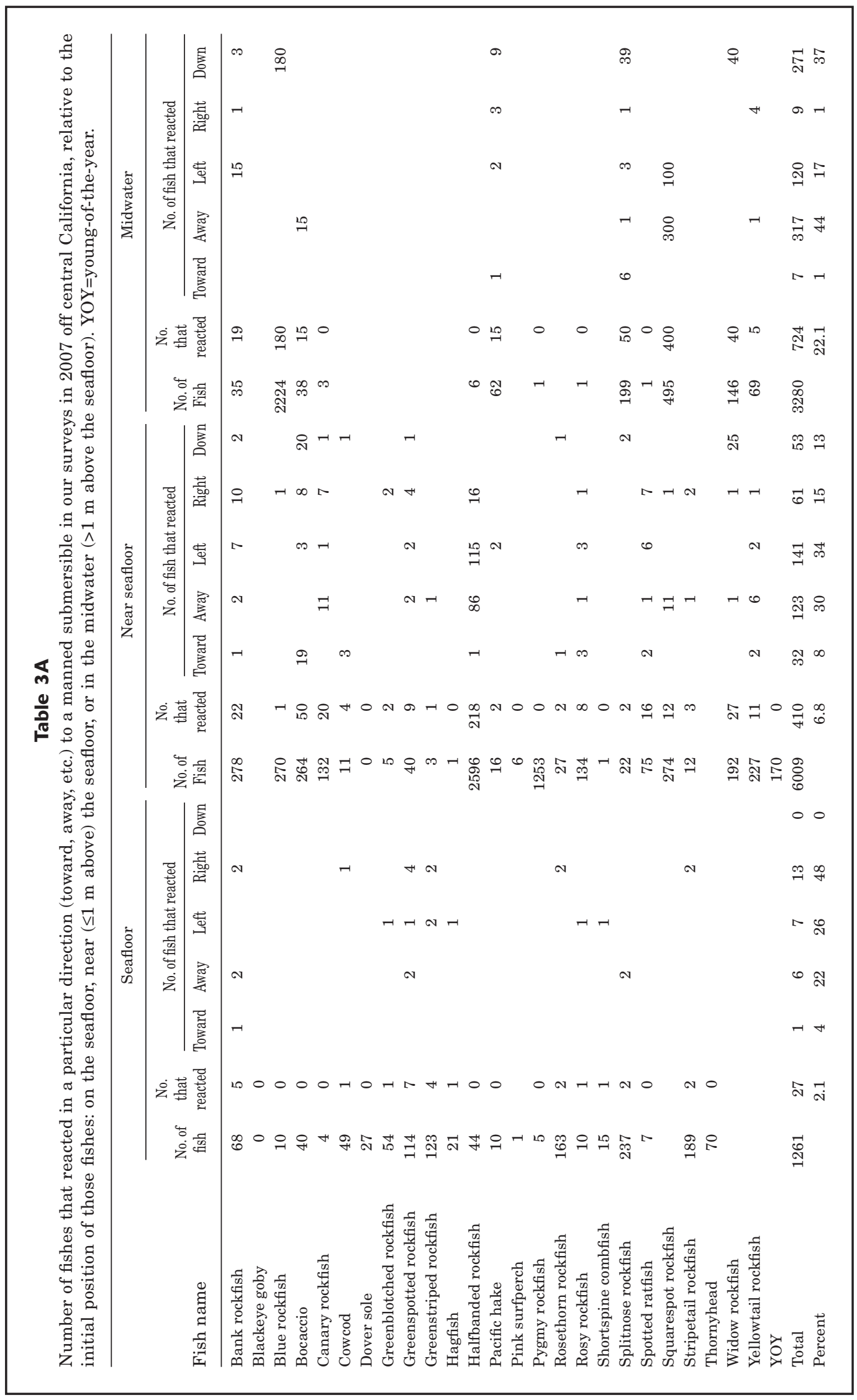




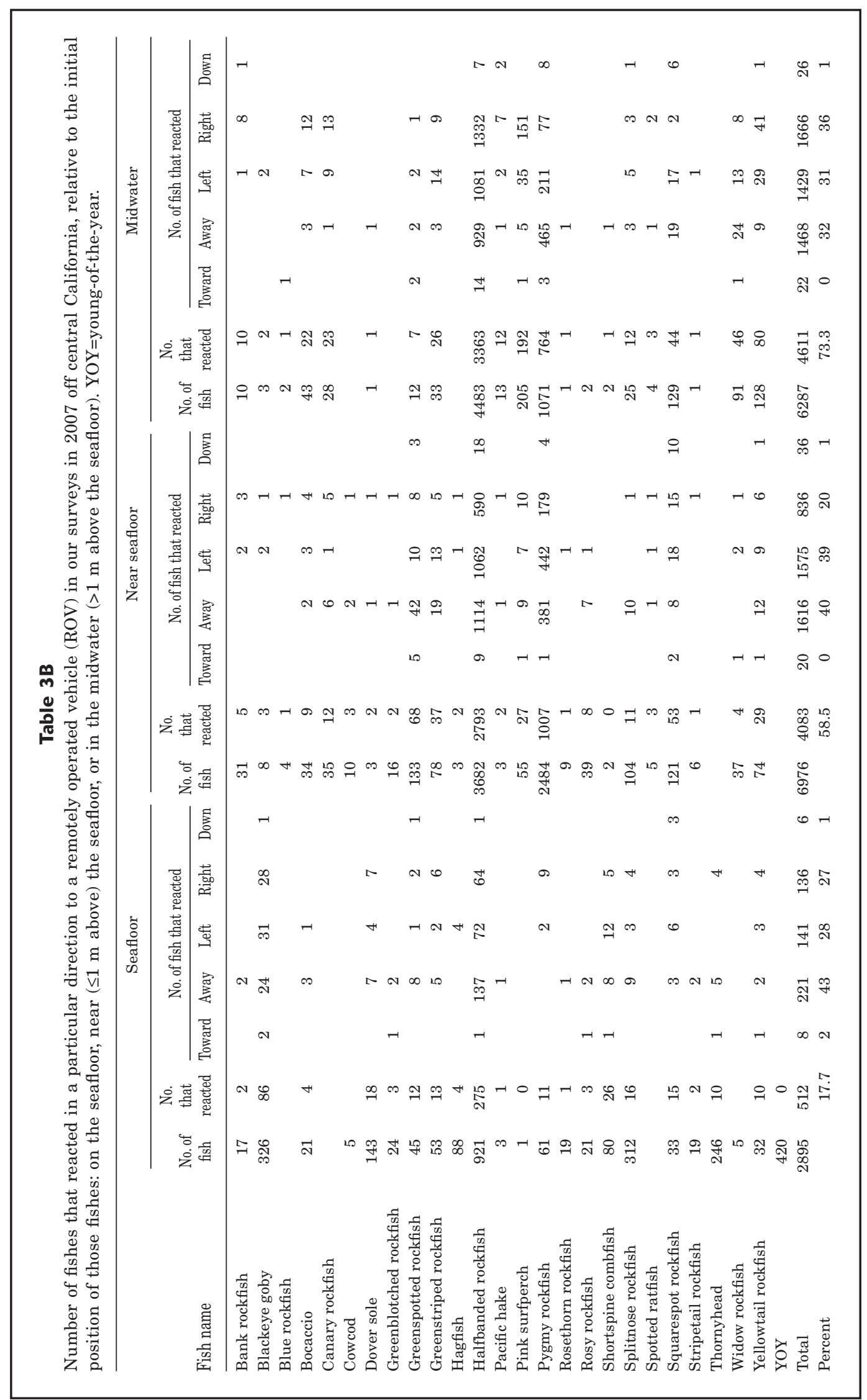




\section{Table 4}

Number of fishes reacting within $3 \mathrm{~m}$ or $>3 \mathrm{~m}$ from the front of the manned submersible and the remotely operated vehicle (ROV). "Position" refers to the location where each fish taxon was most frequently observed. S=on the seafloor, $\mathrm{N}=$ near the seafloor, $\mathrm{M}=\mathrm{in}$ midwater ( $>1 \mathrm{~m}$ above seafloor). The total number of fishes $(n)$ observed is indicated for each vehicle.

\begin{tabular}{|c|c|c|c|c|c|c|c|}
\hline & \multirow[b]{3}{*}{ Position } & \multicolumn{3}{|c|}{ Submersible $(n=10,550)$} & \multicolumn{3}{|c|}{ ROV $(n=16,158)$} \\
\hline & & \multicolumn{3}{|c|}{ Number of reacting fishes } & \multicolumn{3}{|c|}{ Number of reacting fishes } \\
\hline & & $<3 \mathrm{~m}$ & $>3 \mathrm{~m}$ & Total & $<3 \mathrm{~m}$ & $>3 \mathrm{~m}$ & Total \\
\hline Bank Rockfish & $\mathrm{N}$ & 8 & 38 & 46 & 14 & 3 & 17 \\
\hline Blackeye Goby & $\mathrm{S}$ & & & 0 & 74 & 17 & 91 \\
\hline Blue Rockfish & M & 2 & 179 & 181 & 0 & 2 & 2 \\
\hline Bocaccio & $\mathrm{N}$ & 57 & 8 & 65 & 30 & 5 & 35 \\
\hline Canary Rockfish & $\mathrm{N}$ & 18 & 2 & 20 & 32 & 3 & 35 \\
\hline Cowcod & $\mathrm{S}$ & 3 & 2 & 5 & 2 & 1 & 3 \\
\hline Dover Sole & $\mathrm{S}$ & & & 0 & 10 & 11 & 21 \\
\hline Greenblotched Rockfish & $\mathrm{S}$ & 2 & 1 & 3 & 5 & 0 & 5 \\
\hline Greenspotted Rockfish & $\mathrm{S}, \mathrm{N}$ & 10 & 6 & 16 & 55 & 32 & 87 \\
\hline Greenstriped Rockfish & $\mathrm{S}$ & 2 & 3 & 5 & 66 & 10 & 76 \\
\hline Hagfishes & $\mathrm{S}$ & 1 & 0 & 1 & 4 & 2 & 6 \\
\hline Halfbanded Rockfish & $\mathrm{N}, \mathrm{M}$ & 84 & 134 & 218 & 1258 & 5173 & 6431 \\
\hline Pacific Hake & $\mathrm{M}$ & 11 & 6 & 17 & 13 & 2 & 15 \\
\hline Pink Seaperch & $\mathrm{N}, \mathrm{M}$ & & & 0 & 211 & 8 & 219 \\
\hline Pygmy Rockfish & $\mathrm{N}$ & & & 0 & 1201 & 581 & 1782 \\
\hline Rosethorn Rockfish & M & 0 & 4 & 4 & 2 & 1 & 3 \\
\hline Rosy Rockfish & $\mathrm{N}$ & 7 & 2 & 9 & 11 & 0 & 11 \\
\hline Shortspine Combfish & $\mathrm{S}$ & 1 & 0 & 1 & 23 & 4 & 27 \\
\hline Splitnose Rockfish & $\mathrm{S}, \mathrm{N}, \mathrm{M}$ & 14 & 40 & 54 & 29 & 10 & 39 \\
\hline Spotted Ratfish & $\mathrm{N}$ & 10 & 6 & 16 & 4 & 2 & 6 \\
\hline Squarespot Rockfish & $\mathrm{N}, \mathrm{M}$ & 301 & 111 & 412 & 68 & 44 & 112 \\
\hline Stripetail Rockfish & $\mathrm{S}$ & 2 & 3 & 5 & 2 & 2 & 4 \\
\hline Thornyheads & $\mathrm{S}$ & & & 0 & 4 & 6 & 10 \\
\hline Widow Rockfish & $\mathrm{N}, \mathrm{M}$ & 26 & 41 & 67 & 4 & 46 & 50 \\
\hline Yellowtail Rockfish & $\mathrm{N}, \mathrm{M}$ & 12 & 4 & 16 & 37 & 82 & 119 \\
\hline YOY Rockfishes & $\mathrm{S}, \mathrm{N}$ & & & 0 & & & 0 \\
\hline Total & & 571 & 590 & 1161 & 3159 & 6047 & 9206 \\
\hline Percentage of fish reactions & & 49 & 51 & & 34 & 66 & \\
\hline Percentage of all fishes & & 5 & 6 & & 20 & 37 & \\
\hline
\end{tabular}

Sablefish (Anoplopoma fimbria) and $39 \%$ of all Pacific Hake. Lorance and Trenkel (2006) observed that all 8 taxa seen in the Bay of Biscay, in habitat types ranging from flat to gentle slopes and from fine sediments to boulders, reacted to a large working-class ROV with rates from $10 \%$ to $90 \%$. Uiblein et al. (2003), also in the Bay of Biscay, worked with a 3-person submersible to study fish behavior and found that most of the 7 more abundant taxa reacted to the vehicle by markedly changing their activity level. Two species observed in both of these studies (Roundnose Grenadier [Coryphaenoides rupestris] and Orange Roughy) reacted more often to the ROV than to the submersible.

In our study, fishes that lived in the midwater above the seafloor reacted to both the Delta submersible and the Phantom ROV at a higher rate than did fishes on the seafloor. Similar results have been reported in other studies. Krieger and Ito (1999) observed that all Shortraker (Sebastes borealis) and Rougheye ( $S$. aleutianus) Rockfishes that occurred above the seafloor reacted by swimming toward the seafloor as the Delta submersible approached, but only 5 out of the 531 recorded fishes of these 2 species moved when initially seen on the seafloor. Lorance and Trenkel (2006) examined the reactions of 8 fish taxa in the Bay of Biscay and observed that most species reacted to the working-class ROV; only the seafloor-dwelling, deep-sea Atlantic Thornyhead (Trachyscorpia cristulata echinata) had little reaction to the vehicle. In that study, 2 of the 3 taxa that had the greatest reactions (shark species of the order Squaliformes and the family Scyliorhinidae) were commonly encountered as they swam high in the water column. Adams et al. (1995) 


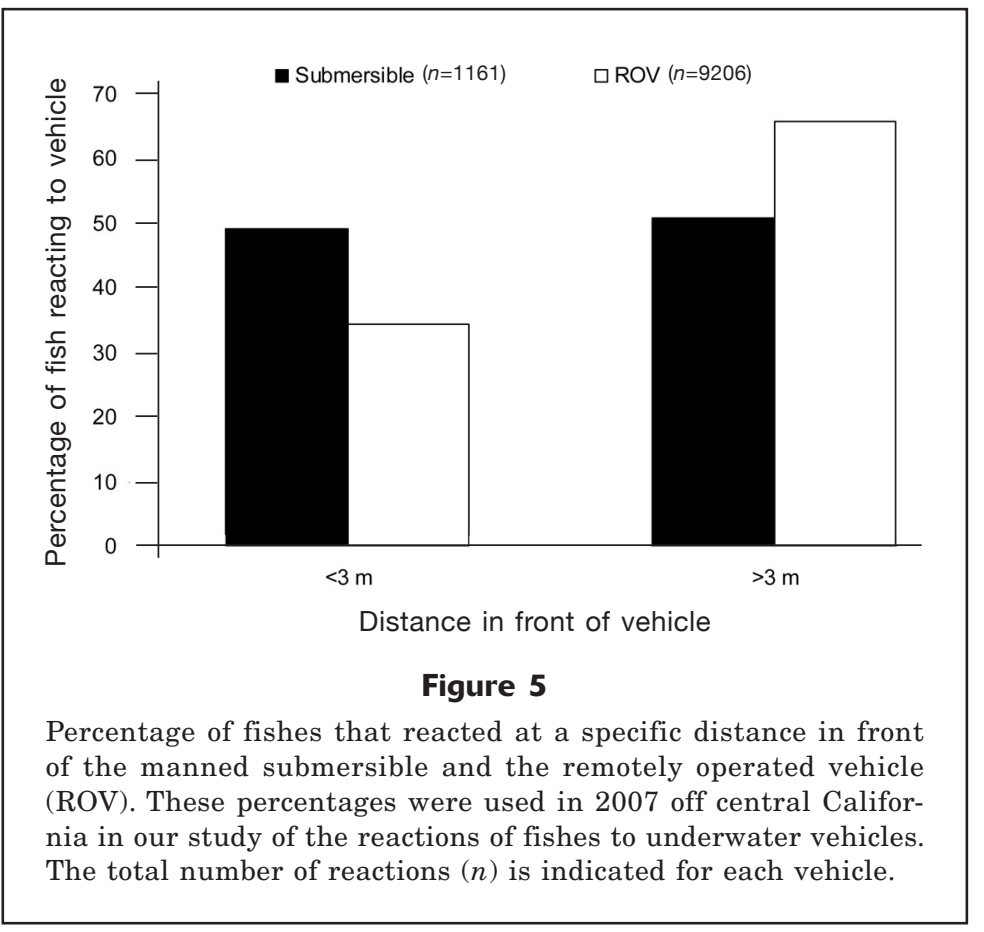

hicle for target species and environmental conditions. Through such efforts, researchers will gain a better understanding of the effectiveness and limitations of potential survey vehicles.

\section{Acknowledgments}

We thank R. Starr, co-principal investigator of the Delta submersible cruise; J. Butler for the use and operation of the ROV; S. Mau for piloting the ROV; Delta Oceanographics; and the crews of the FV Velero IV and the David Starr Jordan. We thank M. Love, M. Nishimoto, T. O'Connell, and D. Watters for help with data collection. D. Watters also created the map of our study site. We also thank C. Rooper, S. Sogard, K. Stierhoff, R. Starr, and L. Wedding for their helpful comments on early versions of this manuscript. This study was funded in part by a grant from the California Ocean Protection Council to R. Starr and M. Yoklavich.

used a working-class ROV and Starr et al. (1996) used the Delta submersible to estimate fish abundance; both studies determined that these vehicles were not reliable in assessment of the abundance of fishes well above the seafloor.

\section{Conclusions}

What are the implications of the reaction of a fish to a survey vehicle? If the reaction occurs over a small distance and the fish remains inside the survey transect, then the fish would be counted and its reaction would not affect the outcome of the survey. However, some reactions (both large and small in magnitude) could cause a fish to move out of the survey transect or out of view (e.g., into a hole or behind a rock)-behavior that would, thereby, bias the resultant abundance estimate. Similarly, overestimates of abundance could be made if a fish moves into a transect because of its reaction to a survey vehicle.

Reactions of the target species need to be considered in selection of a survey vehicle, and the limitations of vehicles need to be evaluated relevant to the goals of a study. For instance, a comparative study can be undertaken to estimate abundance and reaction rates of fish species with various underwater vehicles (e.g., a submersible, ROV, camera sled, an autonomous underwater vehicle, or drop camera) within a specific survey area or over particular transects. From this type of study, the reaction of fishes and abundance estimates can be ascertained for each vehicle, thereby aiding in the selection of an appropriate survey ve-

\section{Literature cited}

Adams, P. B., J. L. Butler, C. H. Baxter, T. E. Laidig, K. A. Dahlin, and W. W. Wakefield.

1995. Population estimates of Pacific coast groundfishes from video transects and swept-area trawls. Fish. Bull. 93:446-455.

Baker, K. D., R. L. Haedrich, P. V. R. Snelgrove, V. E. Wareham, E. N. Edinger, and K. D. Gilkinson.

2012. Small-scale patterns of deep-sea fish distributions and assemblages of the Grand Banks, Newfoundland continental slope. Deep Sea Res. 65:171-188.

Benefield, M. C., J. H. Caruso, and K. J. Sulak.

2009. In situ video observations of two manefishes (Perciformes: Caristiidae) in the mesopelagic zone of the northern Gulf of Mexico. Copeia 2009:637-641.

Carlson, H. R., and R. R. Straty.

1981. Habitat and nursery grounds of Pacific rockfish, Sebastes spp., in rocky coastal areas of Southeastern Alaska. Mar. Fish. Rev. 43:13-19.

Costello, M. J., M. McCrea, A. Freiwald, T. Lundälv, L. Jonsson, B. J. Bett, T. C. E. van Weering, H. de Haas, J. M. Roberts, and D. Allen.

2005. Role of cold-water Lophelia pertusa coral reefs as fish habitat in the NE Atlantic. In Cold-water corals and ecosystems (A. Freiwald and J. M. Roberts, eds.), p. 771-805. Erlangen Earth Conference Series. Springer-Verlag, Berlin.

Davis, C. L., L. M. Carla, and D. O. Evans.

1997. Use of a remotely operated vehicle to study habitat and population density of juvenile lake trout. Trans. Am. Fish. Soc. 126:871-875.

Else, P., L. Haldorson, and K. Krieger.

2002. Shortspine thornyhead (Sebastolobus alascanus) abundance and habitat associations in the Gulf of Alaska. Fish. Bull. 100:193-199. 
Eschmeyer, W. N, E. S. Herald, and H. Hammann. 1983. A field guide to Pacific Coast fishes of North America, 336 p. Houghton Mifflin Co., Boston, MA.

Gartner, J. V., K. J. Sulak, S. W. Ross, and A. M. Necaise. 2008. Persistent near-bottom aggregations of mesopelagic animals along the North Carolina and Virginia continental slopes. Mar. Biol. 153:825-841.

Gibbons, M. J., A. J. J. Goosen, and P. A. Wickens.

2002. Habitat use by demersal nekton on the continental shelf in the Benguela ecosystem, southern Africa. Fish. Bull. 100:475-490.

Hilborn, R., I. J. Stewart, T. A. Branch, and O. P. Jensen. 2011. Defining trade-offs among conservation, profitability, and food security in the California Current bottomtrawl fishery. Conserv. Biol. 26:257-266.

Johnson, S. W., M. L. Murphy, and D. J. Csepp.

2003. Distribution, habitat, and behavior of rockfishes, Sebastes spp., in nearshore waters of southeastern Alaska: observations from a remotely operated vehicle. Environ. Biol. Fishes 66:259-270.

Koslow, J. A., R. Kloser, and C. A. Stanley.

1995. Avoidance of a camera system by a deepwater fish, the orange roughy, (Hoplostethus atlanticus). Deep Sea Res. 42:233-244.

Krieger, K. J.

1993. Distribution and abundance of rockfish determined from a submersible and by seafloor trawling. Fish. Bull. 91:87-96.

Krieger, K. J., and D. H. Ito.

1999. Distribution and abundance of shortraker rockfish, Sebastes borealis, and rougheye rockfish, S. aleutianus, determined from a manned submersible. Fish. Bull. 97:264-272.

Krieger, K. J., and M. F. Sigler.

1996. Catchability coefficient for rockfish estimated from trawl and submersible surveys. Fish. Bull. 94:282-288.

Laidig, T. E., D. L. Watters, and M. M. Yoklavich.

2009. Demersal fish and habitat associations from visual surveys on the central California shelf. Estuar. Coast. Shelf Sci. 83:629-637.

Lorance, P., and V. M. Trenkel,

2006. Variability in natural behaviour, and observed reactions to an ROV, by mid-slope fish species. J. Exp. Mar. Biol. Ecol. 332:106-119.

Love, M. S., M. Yoklavich, and L. Thorsteinson. 2002. The rockfishes of the Northeast Pacific, 414 p. Univ. California Press, Berkeley, CA.

Love, M. S., M. Yoklavich, and D. M. Schroeder.

2009. Demersal fish assemblages in the Southern California Bight based on visual surveys in deep water. Environ. Biol. Fishes 84:55-68.

Luck, D. G., and T. W. Pietsch.

2008. In-situ observations of a deep-sea ceratioid anglerfish of the genus Oneirodes (Lophiiformes: Oneirodidae). Copeia 2008:446-451.

Miller, D. J., and R. N. Lea.

1972. Guide to the coastal marine fishes of California. Calif. Fish Game, Fish Bull. 157, 249 p.

Moore, J. A., P. J. Auster, D. Calini, K. Heinonen, K. Barber, and B. Hecker.

2002. False boarfish Neocyttus helgae in the western north Atlantic. Bull. Peabody Mus. Nat. Hist. 49:31-41.
Murie, D. J., D. C Parkyn, B. G. Clapp, and G. G. Krause. 1994. Observations on the distribution and activities of rockfish, Sebastes spp., in Saanich Inlet, British Columbia, from the Pisces IV submersible. Fish. Bull. 92:313-323.

Pearcy, W. G., D. L. Stein, M. A. Hixon, E. K. Pikitch, W. H. Barss, and R. M. Starr.

1989. Submersible observations of deep-reef fishes of Heceta Bank, Oregon. Fish. Bull. 87:955-965.

PFMC (Pacific Fishery Management Council) and NMFS (National Marine Fisheries Service).

2011. Proposed harvest specifications and management measures for the 2011-2012 Pacific Coast groundfish fishery and Amendment 16-5 to the Pacific Coast Groundfish Fishery Management Plan to update existing rebuilding plans and adopt a rebuilding plan for Petrale Sole. Final Environmental Impact Statement, February 2011, 501 p. PFMC, Portland, OR.

Ryer, C. H., A. W. Stoner, P. J. Iseri, and M. L. Spencer.

2009. Effects of simulated underwater vehicle lighting on fish behavior. Mar. Ecol. Prog. Ser. 391:97-106.

Starr, R. M., D. S. Fox, M. A. Hixon, B. N. Tissot, G. E. Johnson, and W. H. Barss.

1996. Comparison of submersible-survey and hydroacoustic-survey estimates of fish density on a rocky bank. Fish. Bull. 94:113-123.

Stoner, A. W., C. H. Ryer, S. J. Parker, P. J. Auster, and W. W. Wakefield.

2008. Evaluating the role of fish behavior in surveys conducted with underwater vehicles. Can. J. Fish. Aquat. Sci. 65:1230-1243.

Trenkel, V. M., R. I. C. Francis, P. Lorance, S. Mahevas, M. Rochet, and D. M. Tracey.

2004a. Availability of deep-water fish to trawling and visual observation from a remotely operated vehicle (ROV). Mar. Ecol. Progr. Ser. 284:293-303.

Trenkel, V. M., and P. Lorance.

2011. Estimating Synaphobranchus kaupii densities: contribution of fish behaviour to differences between bait experiments and visual strip transects. Deep Sea Res. 58:63-71.

Trenkel, V. M., P. Lorance, and S. Mahevas.

2004b. Do visual transects provide true population density estimates for deepwater fish? J. Mar. Sci. 61:1050-1056.

Uiblein, F., P. Lorance, and D. Latrouite.

2003. Behaviour and habitat utilisation of seven demersal fish species on the Bay of Biscay continental slope, NE Atlantic. Mar. Ecol. Prog. Ser. 257:223-232.

Yoklavich, M. M., M. S. Love, and K. A. Forney.

2007. A fishery-independent assessment of an overfished rockfish stock, cowcod (Sebastes levis), using direct observations from an occupied submersible. Can. J. Fish. Aquat. Sci. 64:1795-1804.

Yoklavich, M. M., and V. M. O'Connell.

2008. Twenty years of research on demersal communities using the Delta submersible in the northeast Pacific. In Marine habitat mapping technology for Alaska (J. R. Reynolds, and H. G. Greene, eds.), p. 143-155. Alaska Sea Grant College Program Report AK-SG-08-03. Univ. Alaska, Fairbanks, AK. doi:10.4027/mhmta.2008.10 